\title{
The Effect of Inflation, Interest Rates And World Oil Prices on Gold Prices in Indonesia With The US Dollar Exchange Rate as an Intermediary Variable
}

\author{
${ }^{1}$ Ummi Kalsum, ${ }^{2}$ Randy Hidayat, ${ }^{3}$ Sheila Oktaviani \\ ${ }^{1,2,3}$ Universitas Muhammadiyah Palembang, Indonesia \\ Email : umminipran04@gmail.com
}

\begin{abstract}
This study aims to determine the effect of inflation, interest rates, and world oil prices on fluctuations in gold prices in Indonesia with the US Dollar exchange rate as an intermediary variable. This research is a type of explanatory research with a quantitative approach. The data used are monthly time series data for $2014-2019$ with a sample of 72 samples. Hypothesis testing in this study uses path analysis, is a development technique of multiple linear regression. This technique is used to test the amount of contribution shown by the path coefficient on each path diagram of the causal relationship between variables $X_{1}, X_{2}$, and $X_{3}$ on and its impact on $Z$. The results of this study indicate that the effect of inflation, interest rates and world oil prices on exchange rates individually has very little effect. The effect of inflation, interest rates, world oil prices and the exchange rate on gold prices individually shows a negative value for inflation and interest rates means that the effect is small, while for the world oil price and the dollar exchange rates shows a positive value which means that it has a large effect on the price of gold. The effect of inflation, interest rates and world oil prices on gold prices through the exchange rate, all variable show a negative value, this indicates that the effect is very small.
\end{abstract}

Keyword: Inflation, Exchange Rates, Interest Rates, World Oil Prices, Gold Prices

\section{Citation}

Kalsum, U., Hidayat, R., \& Oktaviani, S. (2021). The effect of inflation, interest rates and world oil prices on gold prices in Indonesia with the US dollar exchange rate as an intermediary variable. International Journal of Finance Reseach, 2.(1). 1-12.

\section{Introduction}

Investment is an activity related to investing in a variety of alternative assets, both classified as real assets, such as land, gold, property, and in the form of financial assets, such as stocks, bonds, or mutual funds. The purpose of investing is to get benefits in the future. One of the investment products that have been known from ancient times until now is an investment in the form of gold. Gold investment is in great demand by many people for reasons of security and the benefits promised. Generally, they choose to invest in gold to get benefits in the long term, because the value-added of gold is not too big in the short term compared to investing in the stock market. Some of the advantages of choosing gold as an investment are as follows: a). There is no risk in gold when holding gold means holding tangible assets that do not depend on others. b). Consistency of purchasing power, when the price of gold falls means that it will not experience a decrease in wealth because gold has zero inflation. c). It does not depend on government decisions, meaning that when holding gold there is no need to worry about government decisions about interest rates and others. d). Assets that are outside the banking system, meaning that holding gold is free from the vortex of a banking crisis that can 
arise anytime and anywhere. e). Asset value protection, if inflation is high, the price of gold will increase and when the dollar exchange rate rises, the price of gold will also rise. $f$ ). The most effective means of saving for a specific purpose. g). Gold is easy to obtain and very liquid.

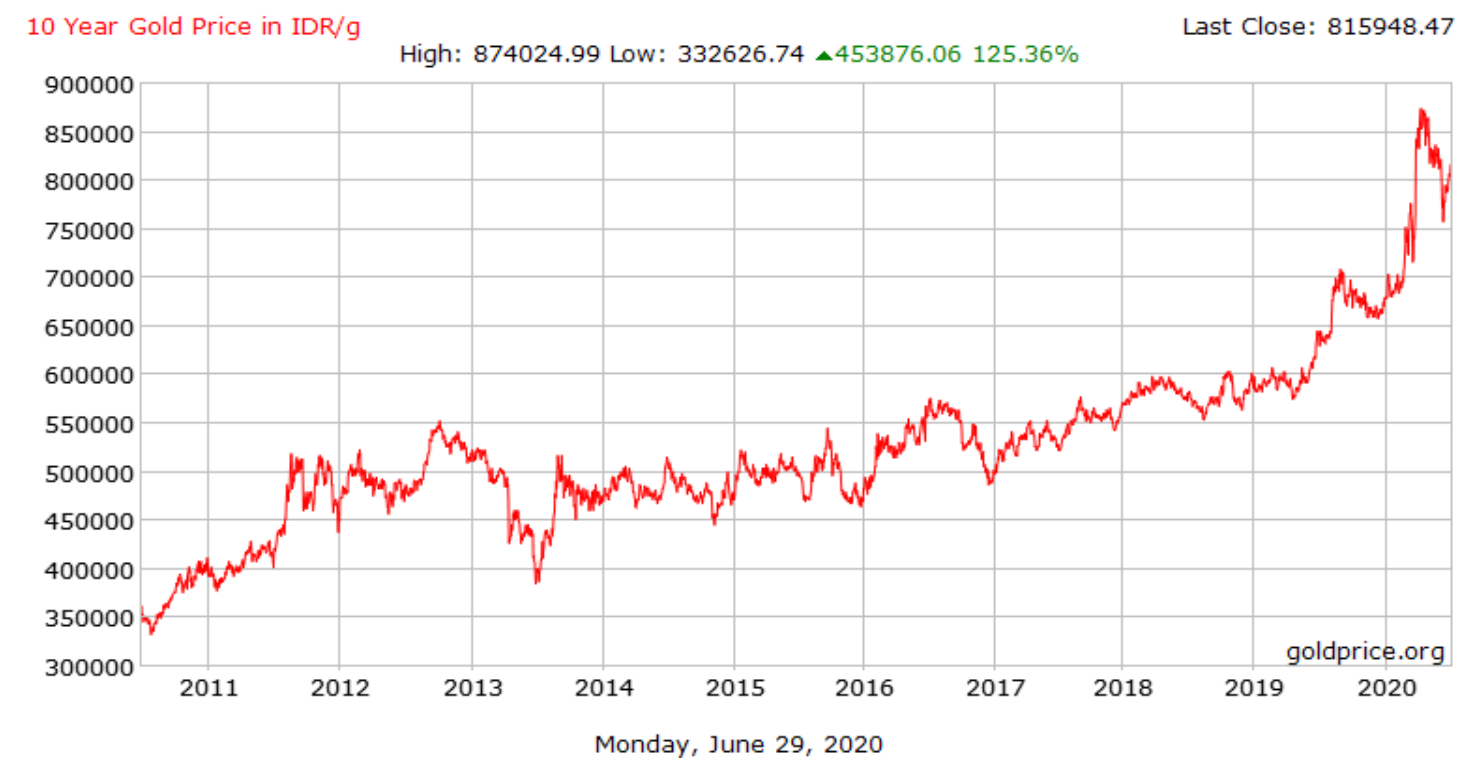

Figure 1. Gold Price Movement Chart (IDR / gram), 2011 - 2020

\section{Source: www.goldprice.org}

Referring to Figure 1, the price of gold can go up and down, but in the long run, it tends to increase. The current price of gold has increased by more than $300 \%$ compared to 10 years ago. The value of this increase is higher than the average rate of inflation in Indonesia. Gold can serve as a hedge for the Indonesian stock market in the long term. This shows that gold can be an instrument of preserving asset value in Indonesia in the long run and found that when extreme shocks occur in the stock market in Indonesia, gold can serve as a haven in the Indonesian (sharia) stock market to Robiyanto (2018). Gold has proven to be a good tool not only to avoid inflation but also to be a profitable investment vehicle. Gold has a limited stock and is not easy to obtain, while the demand for gold never decreases, as a result, the price of gold tends to increase from year to year. The price of gold does not only depend on the demand and supply situation but the price of gold is also influenced by the overall economic situation. Therefore, investors also pay attention to other factors that can affect the price of gold, such as inflation, the US dollar exchange rate, interest rates, and world oil prices.

Inflation can affect gold because if inflation occurs, commodity prices and production costs will increase. As a result, house prices, car prices, basic goods, and gold tended to increase as well. Therefore, when inflation is predicted to occur, the demand for gold usually increases, because gold is considered to protect their wealth from a decrease in the purchase value. This will then affect increasing the price of gold. According to Nurulhuda and Kosasih (2019), inflation has a significant positive effect on Antam's gold price. This shows that when a high inflation rate tends to encourage someone to shift their investment instruments to gold. When inflation rises, the value of the currency falls and so people tend to keep money in gold

When interest rates rise. There is a greater effort to keep money on deposit than in interestfree gold. This will put pressure on the gold price. Conversely, when interest rates fall, the 
price of gold will tend to rise. In theory, if short-term interest rates go up, then the price of gold falls. In Indonesia, this theory does not always work. Suharto and MM (2013) in his research stated that if the interest rate would go down, then interest in buying gold would increase so that the price of gold would increase. According to Nurulhuda and Kosasih (2019), if interest rates increase, in the long run, this influence will be one of the factors that can reduce the price of gold, the result of this increase will be in the spotlight of investors who prefer to invest their funds in the money market or savings and deposits. instead of buying gold that has no interest. This of course will reduce the demand for gold and in the end, will weaken the price of gold.

The next factor that affects the ups and downs of gold prices is the world oil price. According to Tanuwidjaja (2009), when the world crude oil price increases, the gold price on the world market will also increase. Indeed, the effect does not occur immediately, but the price of gold must follow the increase. According to Yuswandy (2013), world oil prices have a significant negative effect on market returns. Meanwhile, according to Suwandy, Muharam \& Pengestuti (2014), the fluctuation of the LQ 45 index is sensitive to world oil prices in a negative direction which indicates that an increase in world oil prices will cause a decrease in the return on the LQ 45 index.

The weakening of the US Dollar exchange rate usually encourages an increase in world gold prices. This is because investors choose to sell their dollar currency and then buy gold which is considered capable of protecting the value of their assets. Nurulhuda and Kosasih (2019) state that exchange rates have a positive and significant effect on Antam's gold price determination. Because the world gold price is determined using the US Dollar currency, the relationship between the gold price and the dollar is closely related. There are several conditions where when the dollar exchange rate rises, the gold price decreases, the movement of the US Dollar has the effect of fluctuating gold prices.

From previous research which proved different results, the researchers were motivated to carry out further research. Researchers want to know what factors influence the fluctuation of gold prices in Indonesia, so the researcher will further examine the "Effect of Inflation, Interest Rates and World Oil Prices on Gold Prices in Indonesia with the US Dollar Exchange Rate as an Intermediary Variable".

Based on the problems that have been described in the background above, the problems that will be discussed are narrowed down, among others

1) How much influence do inflation, interest rates, and world oil prices have on the dollar exchange rate individually?

2) How much influence do inflation, interest rates, world oil prices, and the dollar exchange rate have on the price of gold?

3) How much influence will inflation, interest rates and world oil prices have on gold prices through the dollar exchange rate as an intermediary variable?

\section{Literature Review}

\subsection{Efficient Market Concept}

The price of gold in the market always fluctuates up and down which is a reflection of all related information, how fast the information is reflected in the price of gold indicates how efficient the gold market is. The concept of an efficient market was first put forward by Malkiel (2011) where the level of market efficiency can be divided into 3 according to its 
information sources, namely weak-form efficient market, semi-strong form efficient market, and strong form marketplace (strong form efficient). In the market, there is a lot of information, both fundamental, technical, micro, and macro which will affect the price. For investors, the concept of market efficiency is very important in the framework of using and selecting relevant information for decision making.

\subsection{Inflation Rate}

The theory of inflation is divided into two groups, namely the monetary concept and the nonmonetary concept. The classical theory adopts monetarism, where the money supply or the money supply has a direct relationship with changes in the price level. An increase in the money supply pushes the price level upward, and a decreasing money supply pushes the price level downward. So, the Classical Theory is also called the Quantity Theory of Money.

Inflation according to Classical Theory is not related to other macro variables such as interest rates and unemployment rates. In simple terms, it states that the price level or inflation rate will change if the money in circulation does not match the amount demanded. If the money in circulation is greater than the quantity of money demanded, the price level increases, and inflation occurs.

According to the non-monetary concept, namely Structuralist Theory and Post Keynessian Theory. The structuralist theory states that inflation occurs because of an imbalance in the economy. Inflation is associated with structural factors of the economy which can only change gradually and in the long run. This theory shows that inflation is not merely a monetary phenomenon, but also a structural phenomenon. This structural theory reflects cases of inflation in developing countries, for example, crop failure, production rigidity, foreign debt, and foreign exchange rates. This can lead to price fluctuations in the domestic market.

According to the Keynesian Theory, the quantity of money is not the only factor determining the price level. An economy can experience inflation even though the quantity level of money remains constant. Keynesians state that inflation occurs when the total demand for goods and services exceeds the total supply when in a full-employment position or exceeds its potential output. According to Keynes, several factors can influence the price level, namely household consumption expenditure, investment expenditure, government spending, and taxes. Inflation occurs because people want to live outside the limits of their economic capacity, causing the effective demand of society for goods to exceed the number of goods available, as a result, it will cause an inflation gap. The Keynesian model is mainly used to explain the phenomenon of inflation in the short run.

According to Fahmi (2012), there are four categories of the inflation assessment scale, namely:

1) Inflation is classified as light (creeping inflation), which is an inflation rate of less than $10 \%$ per year. This inflation will have no impact on the economy.

2) Inflation is categorized as moderate (moderate inflation), which is an inflation rate between $10 \%$ to $30 \%$ per year. The impact of this category of inflation is quite felt for people with fixed income.

3) Heavy category inflation is an inflation rate between $30 \%$ to $100 \%$ per year. Where the economic sectors have begun to experience paralysis, except those controlled by the state.

4) Inflation is classified as very heavy (hyperinflation), is an inflation rate above $100 \%$ per year, and causes a prolonged economic crisis. 
According to Nurulhuda and Kosasih (2019), Antam's gold price will increase if inflation rises. If there is an increase in the rate of inflation, when the economic turmoil is uncertain and causes inflation to rise, investors are looking for other alternatives to invest in a safer and easier type, namely gold.

\subsection{Interest rate}

The interest rate is the price for the use of money which is usually expressed in percent (\%) for a certain period. The classical interest rate theory is a theory of demand and supply of savings, where the interest rate is a balancing factor between the demand and supply of investable funds which originates from savings. According to this theory, people's saving is a function of the interest rate. The higher the interest rate, the higher the desire of the people to save. This means that when interest rates are higher, people will be motivated to sacrifice or reduce expenditure for consumption to increase their savings. Investment is also a function of the interest rate (Fahmi, 2012). The higher the interest rate, the lower the people's desire to invest. This is because the cost of using funds (cost of capital) becomes more expensive, and conversely the lower the interest rate, the more the desire to invest will increase. In Indonesia, the nominal interest rate is known as the BI rate, the BI rate is set by the Bank of Indonesia and announced to the public. The BI rate is announced by the Board of Governors of Bank Indonesia at every monthly Board of Governors Meeting and implemented in monetary operations conducted by Bank Indonesia through liquidity management in the money market to achieve operational means of monetary policy (www.bi.go.id)

According to Suharto and MM (2013), an increase in interest rates will result in a decrease in the price of gold and vice versa. Due to the increase in interest rates, investors will prefer to invest their money in the money market or savings or deposits rather than investing in precious metals that have no interest. Nurulhuda and Kosasih (2019) show that the interest rate (BI rate) has a negative effect on the price of gold. If the interest rate increases, in the long run, this effect will be one of the factors that can reduce the price of gold.

\subsection{World Oil Prices}

Petroleum is a mining material that requires special management before it can be used. Crude oil is processed by distillation to produce petroleum with certain variants. Because the production process is complicated and not all countries have petroleum resources, oil is a very valuable item. Because it is very specific and becomes the foundation of almost all of the earth's population, petroleum management also involves high-level political policies (Basundoro, 2017). Classification of crude oil, namely:

1) Brent Blend

This name comes from the geographic location from which this oil is extracted. This type of oil mixture mainly comes from wells located in the northern seas of Europe. Brent Blend is considered to be a sweet crude oil with a content of $0.37 \%$ sulfur and a density of 38.06 degrees. That's because this type of oil is categorized as light crude oil which is mainly used to make gasoline. Most of the Brent Blend is traded in the United States and Mediterranean Countries.

2) West Texas Intermediate (WTI)

This type of oil has low sulfur and density. The sulfur content ranges from $0.24 \%$ and the gravity or density is 39.6 degrees. This oil is called sweet and light crude oil and is considered to have good qualities for processing into gasoline. The distillery is mainly carried out in the Gulf area and the United States. 
3) Russian Export Blend

This type of oil is the reference for Russian crude and has a density of 32 degrees and a sulfur content of $1.2 \%$. The high sulfur content makes the Russian Export Blend classified as acid oil and has a medium (medium) density. The price of this type of oil is generally determined from the two main delivery locations, namely Italy and the Netherlands.

4) Dubai Crude

As the name suggests, this oil comes from one of the largest oil-producing countries in the world, namely Dubai. The resulting oil has a low density with a gravity of 31 degrees and a sulfur content of $2 \%$. Dubai crude is used as the reference price for oil exported in Asia.

According to Yuswandy (2013), world oil prices have a negative effect on market returns. Indirectly, the increase in world government prices will have an impact on the export and import sectors of a country.

\subsection{Exchange Rate}

Currency exchange rate or often referred to as exchange rate is the price of one unit of foreign currency in domestic currency or it can also be said that the price of domestic currency against foreign currency. According to Simorangkir (2004), the factors that influence the exchange rate depend on the amount of demand and the amount of supply of foreign exchange. Judging from the factors that influence it, three main factors affect the demand for foreign currency, namely:

1) Import payments.

The higher the imports of goods and services, the greater the demand for foreign currency so that the exchange rate tends to weaken. Conversely, if imports decline, the demand for foreign currency will decline, which will encourage the strengthening of the exchange rate.

2) Capital outflow.

The greater the capital outflow, the greater the demand for foreign exchange, and in the end, it will weaken the exchange rate. Capital outflows include the payment of debts of Indonesian residents (both private and government) to foreigners and placement of Indonesian residents' funds abroad.

3) Speculative activity.

The more foreign exchange speculation activities carried out by speculators, the greater the demand for foreign currency.

The supply of foreign currency is influenced by two factors, namely:

1) Receipt of export results

The greater the volume of export receipts of goods and services, the greater the amount of foreign exchange owned by a country, and ultimately the exchange rate against foreign currencies tend to strengthen or appreciate. If exports decline, the amount of foreign currency held will decrease so that the exchange rate tends to depreciate.

2) Capital inflow

The greater the capital inflow, the stronger the exchange rate tends to be. Capital inflows can be in the form of receiving foreign debt, placing short-term funds by foreigners (portfolio investment), and foreign direct investment. 


\subsection{Gold price}

Gold as a metal is a chemical element that has the symbol $\mathrm{Au}$ and atomic number 79 . The chemical properties of gold are inert, meaning that it does not readily react with other chemical elements. Gold will remain shiny even though it has been buried in the ground or at the bottom of the ocean for a long time. Gold is a metal that has a very high value in all cultures in the world, even in its raw form. According to Tanuwidjaja (2009), the benefits of gold in the economic sector are as a medium of trade exchange and used as a country's foreign exchange reserves because of its high and never-depreciating selling value.

\subsection{Hypothesis}

H1 : The effect of inflation, interest rates, and world oil prices on the dollar exchange rate individually.

H2 : Influence of variable inflation, interest rates, world oil prices, and dollar exchange rates on the variable price of gold individually.

H3 : The effect of inflation, interest rates, and world oil prices on the price of gold through the dollar exchange rate.

\section{Research Method}

\subsection{Research design}

This research design uses a causality design, which in this case will analyze the relationship and influence between the variables above, which if there is a relationship, it will also be examined how far the level of influence (significance) of a variable will affect other variables. The approach used in this research is quantitative. Data analysis in this study used time series data regression with a total data of 72 observations.

\subsection{Data collection technique}

This study uses data collection techniques that are based on secondary data collection or in other words using documentary methods. The method of collecting documentation data in this study was carried out by collecting publication data from the BPS website, BI, and the Trade Portal.

\subsection{Operational Research Variables}

1) Dependent Variable

a) Gold Price (Y)

Gold price data used in this study are monthly data. The measurement of the price of gold uses the unit price in rupiah per gram. Gold price data in Indonesia is obtained from the site https://harga-emas.org.

b) USD Exchange Rate (Z)

The rupiah exchange rate used in this study is the rupiah exchange rate against the USD in the form of the middle transaction rate. Measurement of the rupiah exchange rate uses units of IDR / 1 USD. Rupiah exchange rate data is obtained from the website www.bi.go.id.

2) Independent Variable

a) Inflation $\left(\mathrm{X}_{1}\right)$

The data on the inflation rate used is the inflation rate based on the Consumer Price Index (CPI) which is taken from the monthly data on the website www.bps.go.id with 
a calculation in the form of a percentage (\%).

b) Interest Rate $\left(\mathrm{X}_{2}\right)$

The measurement of interest rates using the percentage unit (\%) is obtained from the site www.bi.go.id.

c) World Oil Price $\left(\mathrm{X}_{3}\right)$

The world oil price is a monetary value set to obtain 1 barrel of oil in US dollars. The data used is monthly data on the price of WTI oil in dollars per barrel.

\subsection{Data analysis technique}

Hypothesis testing in this study uses path analysis, path analysis is a development technique of multiple linear regression. This technique is used to test the amount of contribution (contribution) shown by the path coefficient on each path diagram of the causal relationship between variables $\mathrm{X}_{1}, \mathrm{X}_{2}$, and $\mathrm{X}_{3}$ on $\mathrm{Y}$ and its impact on $\mathrm{Z}$.

\section{Findings and Discussions}

Based on the results of calculations using the help of the SPSS for Windows Version 26 program, the results of the data validity test

Table 1. Coefficients ${ }^{\mathrm{a}}$ Dependent Variable Exchange Rate

\begin{tabular}{|c|c|c|c|c|}
\hline & \multirow{2}{*}{ Model } & \multicolumn{2}{|c|}{ Unstandardized Coefficients } & \multirow{2}{*}{$\begin{array}{c}\text { Standardized Coefficients } \\
\text { Beta }\end{array}$} \\
\hline & & B & Std. Error & \\
\hline \multirow[t]{4}{*}{1} & (Constant) & 15595,861 & 423,287 & \\
\hline & Inflation & $-231,594$ & 66,538 &,- 450 \\
\hline & Interest Rate & $-25,917$ & 86,828 &,- 038 \\
\hline & World Oil Prices & $-16,267$ & 4,187 &,- 362 \\
\hline
\end{tabular}

Source: Output SPSS v.26

Table 2. Coefficients ${ }^{\mathrm{a}}$ Dependent Variable Gold Price

\begin{tabular}{llrrr} 
& \multirow{2}{*}{ Model } & \multicolumn{2}{c}{ Unstandardized Coefficients } & Standardized Coefficients \\
\cline { 2 - 5 } & B & Std. Error & Beta \\
\hline \multirow{2}{*}{ (Constant) } & 151291,460 & 113326,664 & \\
& Inflation & $-8198,752$ & 4223,146 &,- 239 \\
& Interest Rate & $-11020,422$ & 5080,487 &,- 242 \\
& World Oil Prices & 607,336 & 270,664 &, 203 \\
& Exchange Rate & 34,284 & 7,091 &, 515 \\
\hline
\end{tabular}

Source: Output SPSS v.26 
From tables 1 and 2 above, a path diagram can be made as below:

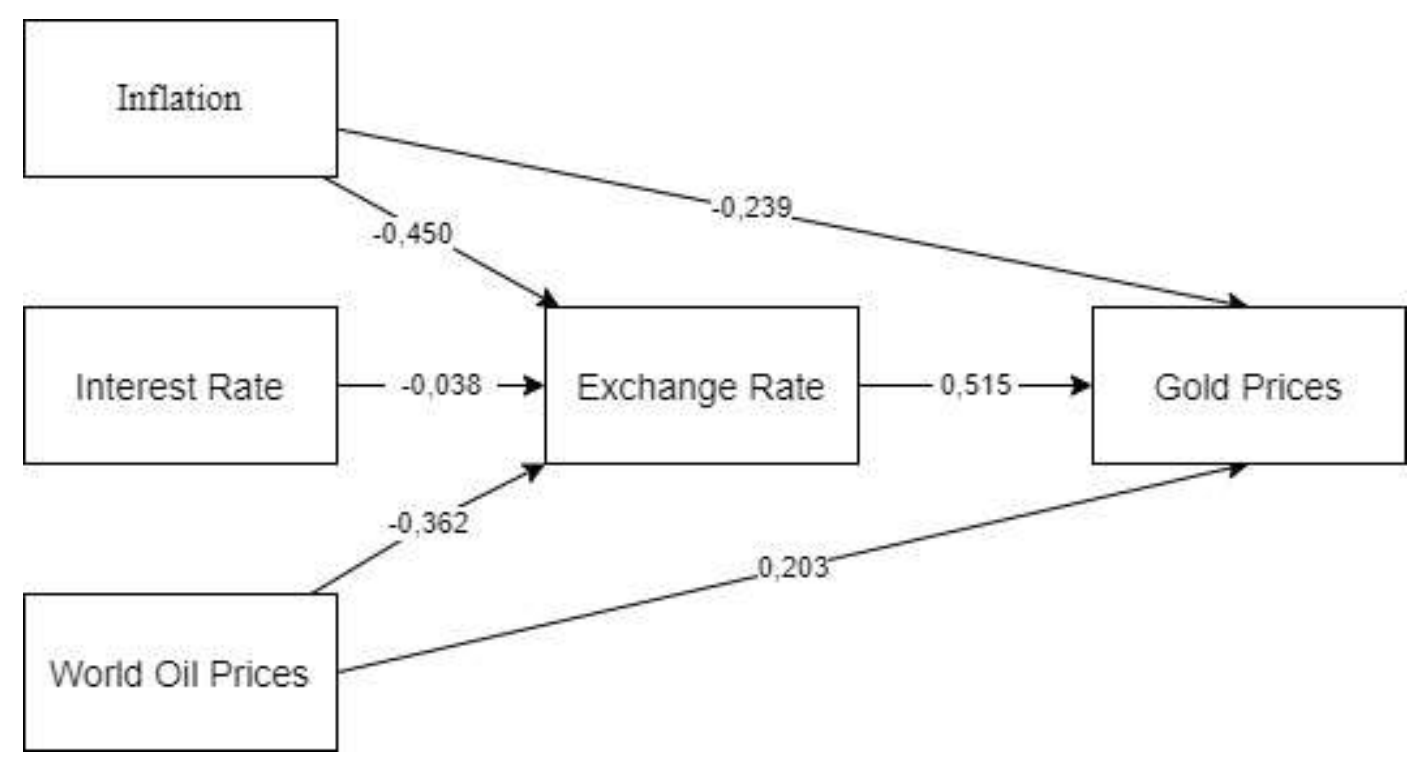

Figure 2. Model Path

Source: author

\subsection{Hypothesis testing}

1) Hypothesis 1. The Influence of Inflation, Interest Rates, and World Oil Prices on Dollar Exchange Rates individually.

a) Inflation $\left(\mathrm{X}_{1}\right)$ to the Dollar Exchange Rate $(\mathrm{Z})$

Based on Figure 3 above, it can be seen that the Inflation variable has a direct effect of -0.450 on the Dollar Exchange Rate Variable

b) Interest Rate $\left(\mathrm{X}_{2}\right)$ to Dollar Exchange Rate $(\mathrm{Z})$

Based on Figure 3 above, it can be seen that the Interest Rate variable has a direct effect of -0.038 on the Dollar Exchange Rate Variable

c) World Oil Price $\left(\mathrm{X}_{3}\right)$ to Dollar Exchange Rate $(\mathrm{Z})$

Based on Figure 3 above, it can be seen that the World Oil Price variable has a direct effect of -0.362 on the Dollar Exchange Rate Variable

2) Hypothesis 2. The influence of the variables of inflation, interest rates, world oil prices, and the dollar exchange rate on the variable price of gold individually.

a) Inflation $\left(\mathrm{X}_{1}\right)$ to the Price of Gold $(\mathrm{Y})$

Based on Figure 3 above, it can be seen that the Inflation variable has a direct effect of -0.239 on the Gold Price Variable

b) Interest Rate $\left(\mathrm{X}_{2}\right)$ to Gold Price $(\mathrm{Y})$

Based on Figure 3 above, it can be seen that the Interest Rate variable has a direct effect of -0.242 on the Gold Price Variable

c) World Oil Price $\left(\mathrm{X}_{3}\right)$ to Gold Price $(\mathrm{Y})$ 
Based on Figure 3 above, it can be seen that the World Oil Price variable has a direct effect of 0.203 on the Gold Price Variable

d) Dollar (Z) to the Gold Price (Y) Exchange Rate

Based on Figure 3 above, it can be seen that the Dollar Exchange Rate variable has a direct effect of 0.515 on the Gold Price Variable

3) Hypothesis 3. The Influence of Inflation, Interest Rates, and World Oil Prices on Gold Prices through the Dollar Exchange Rate.

a) Inflation $\left(\mathrm{X}_{1}\right)$ to the Gold Price $(\mathrm{Y})$ through the Dollar Exchange Rate $(\mathrm{Z})$

Based on Figure 3 above, it can be calculated as follows $-0.450 \times 0.515=-0.230$

b) Interest rate $\left(\mathrm{X}_{2}\right)$ to Gold Price $(\mathrm{Y})$ through Dollar Exchange Rate $(\mathrm{Z})$

Based on Figure 3 above, it can be calculated as follows $-0.038 \times 0.515=-0.019$

c) World Oil Price $\left(\mathrm{X}_{3}\right)$ to Gold Price $(\mathrm{Y})$ through Dollar Exchange Rate $(\mathrm{Z})$

Based on Figure 3 above, it can be calculated as follows $-0.362 \times 0.515=-0.186$

\subsection{Discussion}

Table 3. Direct Effect, Indirect Effect, dan Total Effect

\begin{tabular}{cccccc}
\hline & Variable & & Direct Effect & Indirect Effect & Total Effect \\
\hline $\mathrm{X}_{1}$ & $\rightarrow$ & $\mathrm{Z}$ & -0.450 & - & -0.450 \\
\hline $\mathrm{X}_{2}$ & $\rightarrow$ & $\mathrm{Z}$ & -0.038 & - & -0.038 \\
\hline $\mathrm{X}_{3}$ & $\rightarrow$ & $\mathrm{Z}$ & -0.362 & - & -0.362 \\
\hline $\mathrm{X}_{1}$ & $\rightarrow$ & $\mathrm{Y}$ & -0.239 & $(-0,450 \times 0.515)=-0,230$ & -0.469 \\
\hline $\mathrm{X}_{2}$ & $\rightarrow$ & $\mathrm{Y}$ & -0.242 & $(-0.038 \times 0.515)=-0.019$ & -0.261 \\
\hline $\mathrm{X}_{3}$ & $\rightarrow$ & $\mathrm{Y}$ & 0.203 & $(-0.362 \times 0.515)=-0.186$ & 0.017 \\
\hline $\mathrm{Z}$ & $\rightarrow$ & $\mathrm{Y}$ & 0.515 & - & 0.515 \\
\hline
\end{tabular}

\subsubsection{Great Inflation Effect}

In the hypothesis test, it was found that the effect of inflation, either directly or indirectly, resulted in a minus value, this means that there was no influence of inflation on the gold price through the dollar exchange rate, this was caused by inflation that occurred during the study period, which was included in the category. mild inflation that is below $10 \%$. Low inflation has little effect on prices as a whole.

The results of this study support the research of Septiawan, Hidayat, \& Sulasmiyati (2016) which states that inflation does not affect economic growth. The results of this study do not support the research of Nurulhuda and Kosasih (2019) which found that inflation has a significant positive effect on gold prices.

\subsubsection{Great Influence of Interest Rates}

As with inflation, the effect of interest rates, either directly or indirectly, shows a minus number. This shows that there is a negative relationship between interest rates that has an impact on the determination of the gold price. If interest rates increase, in the long run, this effect will be one of the factors that can reduce the price of gold. Investors will prefer to 
invest their funds in savings or deposits rather than buying gold. When interest rates fall, investors will prefer investing in gold.

\subsubsection{Great Influence of World Oil Prices}

Indonesia is a world oil importer country since 2004. However, Indonesia is also one of the producers of crude oil and refined oil which is exported abroad, so that Indonesia will also benefit from an increase in world oil prices because this will also be followed by an increase in prices. selling ICP (Indonesian Crude Price).

The world oil price directly has a positive effect value of 0.203 on the price of gold. If there is an increase in world oil prices, then the price of gold will also increase. The increase in world oil prices will increase demand for other energy sources. Indonesia is a world oil importer, besides that, it is also a producer of crude oil and refined oil.

The world oil price through the Dollar Exchange rate a effect value 0.017 to the Gold Price. This implies that through the Dollar Exchange Rate, the Gold Price will not increase or decrease. Broadly speaking, all related aspects will improve with each other. However, in this case, the Dollar Exchange rate does not have much influence on other aspects such as oil and gold. Because in some circumstances it will be very possible for the dollar exchange rate to continue to soar up. In contrast to the oil and gold prices, although they experience an increase, there is little possibility for a decline.

\section{Conclusions}

Based on the result of the research and discussion the authors conclude that : (1) The magnitude of the influence of inflation, interest rates and world oil prices on the exchange rate individually shows a negative or very small effect; (2) ) The magnitude of the influence of inflation, interest rates, world oil prices and the exchange rates on gold prices individually shows a negative value for inflation and interest rates means that the effect is small, while for the world oil price and the dollar exchange rate it shows positive value which means that it has a large influence on prices gold; (3) The influence of inflation, interest rates and world oil price on gold prices through the exchange rate, all variable show a negative value, this indicates that the effect is very small.

\section{References}

Basundoro, P. (2017). Minyak Bumi dalam Dinamika Politik dan Ekonomi Indonesia 19501960an. Airlangga University Press.

Fahmi, I. (2012). Analisis Kinerja Keuangan. Alfabeta.

Tanuwidjaja, W. (2009). Cerdas Investasi Emas. Media Pressindo.

Malkiel, B. G. (2011). The Efficient-Market Hypothesis and the Financial Crisis. Rethinking the Financial Crisis, 75-98. Retrieved from http://www.russellsage.org/sites/all/files/Rethinking-Finance/Malkiel.\%20The\%20EfficientMarket\%20Hypothesis\%20and\%20the\%20Financial\%20Crisis\%20102611.pdf

Nurulhuda, E. S., \& Kosasih, K.. (2019). Pengaruh Inflasi, Kurs Dollar US, dan Suku Bunga (BI) Terhadap Penentuan Harga Emas. Kinerja, 2 (01), 71-94.

Robiyanto, R. (2018). Testing of the Gold's Role as a Safe Haven and Hedge for Sharia Stocks in Indonesia. Al-Iqtishad Journal of Islamic Economics, 10(2), 255-266. 
Septiawan, D. A., Hidayat, R. R., \& Sulasmiyati, S. (2016). Pengaruh Harga Minyak Dunia, Inflasi, Dan Nilai Tukar Terhadap Pertumbuhan Ekonomi Indonesia (Studi Pada Tahun 20072014). Jurnal Administrasi Bisnis (JAB), 40(2), 130-138.

Simorangkir, I. (2004). Sistem dan Kebijakan Nilai Tukar. Seri Kebanksentralan, (12). Bank Indonesia.

Suharto, F. T., \& MM, S. (2013). Harga Emas Naik atau Turun, Kita Tetap Untung. Elex Media Komputindo.

Suwandy, T. Muharam, H., \& Pengestuti, I. D. (2014). Analisis Pengaruh Inflasi, Nilai Ttukar, BI Rate, Harga Minyak Dunia, Harga Emas Dunia Terhadap Indeks LQ 45 pada Bursa Efek Indonesia. Jurnal Bisnis Strategi, 23(1). 43-58.

Yuswandy, Y. (2013). Analisis pengaruh harga minyak dunia, harga emas dunia, nilai tukar RP terhadap USD dan indeks IHSG terhadap return saham (Studi kasus saham-saham Sinarmas Group) (Doctoral dissertation, Tesis. Universitas Bogor Agricultural).

\section{Copyrights}

Copyright for this article is retained by the author(s), with first publication rights granted to the journal.

This is an open-access article distributed under the terms and conditions of the Creative Commons Attribution license (http://creativecommons.org/licenses/by/4.0/). 